\title{
Characterizing Phosphorus Removal in Passive Waste Stabilization Ponds in Arctic Communities
}

\begin{tabular}{|r|l|}
\hline Journal: & Arctic Science \\
\hline Manuscript ID & AS-2015-0002.R3 \\
\hline Danuscript Type: & Article \\
\hline Complete List of Authors: & $\begin{array}{l}\text { Schmidt, Jordan; Dalhousie University, Centre for Water Resources Studies } \\
\text { Ragush, Colin; Dalhousie University, } \\
\text { Krkosek, Wendy; Dalhousie University, } \\
\text { Gagnon, Graham; Dalhousie University, } \\
\text { Jamieson, Rob; Dalhousie University, }\end{array}$ \\
\hline Keyword: & wastewater treatment, waste stabilization pond, phosphorus, Arctic \\
\hline
\end{tabular}




\section{Characterizing Phosphorus Removal in Passive}

\section{Waste Stabilization Ponds in Arctic Communities}

Jordan J. Schmidt, Colin M. Ragush, Wendy H. Krkosek, Graham A. Gagnon, Rob C. Jamieson*

Centre for Water Resources Studies, Dalhousie University, 1360 Barrington Street, Halifax, NS Canada

*Tel.: 1-902-494-6791; fax: 1-902-494-3108; email: jamiesrc@dal.ca 


\begin{abstract}
A majority of communities in the Canadian territory of Nunavut rely on passive waste stabilization ponds (WSPs) for domestic wastewater treatment. Little research has been conducted on the treatment performance of these systems. Therefore, in response to impending federal wastewater regulations, a research program was conducted in order to characterize contaminant removal, with phosphorus a contaminant of particular concern. The performance of WSPs in the Arctic communities of Kugaaruk, Pond Inlet, Grise Fiord and Clyde River was evaluated from 2011 to 2014. Removal of total phosphorus was highly variable ranging from 24\% (Pond Inlet, 2014) to 76\% (Grise Fiord, 2011). The average removal efficiency was $44 \%$. Effluent total phosphorus concentrations generally exceeded $7 \mathrm{mg}$ P/L, partly due to elevated raw wastewater concentrations. Over the course of the treatment season (defined as June to September, when the WSP is thawed), limited additional total phosphorus removal was observed. A fractionation analysis of WSP sediments showed that organic phosphorus and phosphorus bound to aluminum and iron were the predominant forms, which provided insight into primary treatment mechanisms. Further studies on these mechanisms are needed in order to optimize Arctic WSP treatment.
\end{abstract}

Keywords: wastewater treatment, waste stabilization pond, phosphorus, Arctic 


\section{Introduction}

Passive systems are the most common form of municipal wastewater treatment in the Canadian Arctic territory of Nunavut. Of the territory's 25 municipal wastewater treatment systems, 21 use passive systems such as waste stabilization ponds (WSPs) and/or wetlands. Passive systems have several advantages including low operating costs, minimal required technical expertise and long retention periods (Heaven et al. 2003). However, their performance can be variable (Hanaeus et al. 2010).

Little research has previously been conducted on the performance of passive systems in northern environments and a comprehensive understanding of the treatment mechanisms occurring in these systems has not been obtained. Therefore, in 2009, when the Canadian Council of Ministers of the Environment (CCME) endorsed the development of a Canada-Wide Strategy for the Management of Municipal Wastewater Effluent, special provisions were allotted for Canada's 'Far North'. Northern regions were allotted five years in which to conduct research into the performance of existing wastewater facilities and factors affecting their performance (CCME 2009).

In Nunavut, passive WSPs used for municipal wastewater treatment are typically designed to provide storage for 365 days of wastewater generation. They are generally ice-free from June to September. Most commonly, WSPs have a controlled decant at the end of the ice-free period. It is generally accepted that any treatment provided occurs primarily during the ice-free period. Therefore, for the purpose of this study, the ice-free period is referred to as the treatment season. Raw wastewater is characterized by high organic/nutrient concentrations attributed to a low per capita water usage. 
The Canada-Wide Strategy set out National Performance Standards for total suspended solids (TSS), 5-day carbonaceous biochemical oxygen demand $\left(\mathrm{CBOD}_{5}\right)$ and total residual chlorine. Effluent discharge objectives for other parameters, such as nutrients, can also be implemented on a site-by-site basis in order to adequately protect human health and the receiving water body. Due to its role in eutrophication, phosphorus is an important parameter for consideration. An initial study of receiving water benthic environments in Nunavut found that effluent from WSPs was causing localized nutrient enrichment (Krumhansl et al. 2015)

Phosphorus can be removed by both biological and chemical mechanisms in a WSP. Biological removal involves the assimilation of phosphorus into bacteria or algal biomass. Promoting algae growth is considered a promising mechanism for Arctic climates due to extended summer photoperiods. Algae consume phosphorus to construct cellular components such as nucleic acids and phospholipids. Phosphorus can also be stored in algae as polyphosphate via a mechanism referred to as luxury uptake (Miyachi et al. 1964). Chemical removal mechanisms involve the precipitation of orthophosphate with calcium, magnesium, aluminum or iron. The complexes formed depend on $\mathrm{pH}$ and temperature, as well as orthophosphate and cation concentration. Phosphate can also adsorb to hydroxides of calcium, iron and aluminum (Moutin et al. 1992; Peng et al. 2007; Wilsenach et al. 2007). Both biological and chemical removal mechanisms ultimately rely on sedimentation for removal from the water column of a WSP.

Highly variable phosphorus removal efficiencies have been demonstrated in Northern climates, depending on the WSP design and operation. Fellingsdams, common in Scandinavian countries, use slaked lime, aluminum sulfate (alum) or ferric chloride as 
precipitants. Fellingsdams in northern Sweden have demonstrated mean phosphorus removals of $84-96 \%$ (Hanaeus 1987; Hanaeus et al. 2010). The main disadvantage of fellingsdams is increased sludge generation, which results in yearly dredging (Hanaeus 1987). Experiments on biological treatment options have also been conducted. Pilot scale high rate algal ponds operated in northern Sweden achieved $11-49 \%$ removal efficiency before experiments ceased in October due to ice formation (Grönlund et al. 2010).

The objective of this study was to characterize phosphorus removal in passive WSPs in northern environments and to identify promising removal pathways. Field research was conducted on four wastewater systems located above the Arctic Circle in Nunavut, Canada. All systems were located in small, remote communities only accessible by airplanes. Frequency of scheduled flights varied from daily to weekly, depending on the community. Relying on airplanes for transportation creates a unique set of challenges including limited ability to ship samples for analysis, inability to access research supplies deemed hazardous and extremely high costs. Within the systems, phosphorus concentrations were measured at various points over the course of four years. Since both chemical and biological removal mechanisms require sedimentation for removal, a phosphorus fractionation analysis was conducted on sediments from two WSPs. Sediment phosphorus fractionation is a method commonly used to study natural ecosystems, but is not widely used in engineered systems. Fractionation methods generally apportion phosphorus into multiple organic and inorganic pools (Goltermann 1996; Lukkari et al. 2007). The fractionation method used in this study, as described by Lukkari et al. (2007), separates total sediment phosphorus into the following pools: loosely bound and pore water phosphorus, redox sensitive iron and manganese bound 
phosphorus, phosphorus bound to aluminum and non-reducible iron oxides, calcium bound phosphorus and organic phosphorus. The results of the sedimentation analysis were used to hypothesize which removal mechanisms are occurring in the WSP environment.

\section{Materials and Methods}

\subsection{Description of sites}

Research was conducted in Kugaaruk, Pond Inlet, Clyde River and Grise Fiord, NU. A map of the sites is shown in Figure 1.

\subsubsection{Kugaaruk (68³1'59” N, 8949’36” W)}

Kugaaruk is located in central Nunavut and has a population of approximately 878 (Nunavut Bureau of Statistics 2013). Kugaaruk has a daily average temperature ( \pm standard deviation) of $-13.5 \pm 1.5^{\circ} \mathrm{C}$ with an average temperature during July and August of $7.9^{\circ} \mathrm{C}$ (Environment Canada 2014). Kugaaruk's wastewater treatment system consists of a single cell WSP with an estimated surface area of $10188 \mathrm{~m}^{2}$ and average operating depth of $5.4 \mathrm{~m}$ during the treatment season. The WSP has an approximate volumetric and organic loading rate of $76 \mathrm{~m}^{3} / \mathrm{d}$ and $28 \mathrm{~kg} \mathrm{BOD} / \mathrm{ha} / \mathrm{d}$, respectively. The WSP is decanted annually from July-October, depending on the weather. During the decant, wastewater is pumped from the WSP into a smaller pond with a downstream permeable berm. Wastewater seeps through the berm into a natural tundra wetland. The purpose of the decant pond is to spread the wastewater flow over the width of the wetland. The outfall of 
the wetland is a marine receiving environment approximately $650 \mathrm{~m}$ from the community.

\subsubsection{Pond Inlet (7241'57” N, 77057'33” W)}

Pond Inlet is located on northern Baffin Island and has a population of approximately 1612 (Nunavut Bureau of Statistics 2013). Pond Inlet has a daily average temperature ( \pm standard deviation) of $-14.6 \pm 4.9^{\circ} \mathrm{C}$ with an average temperature during July and August of $5.7^{\circ} \mathrm{C}$ (Environment Canada 2014). Pond Inlet's system consists of a single cell WSP with an estimated surface area of $40000 \mathrm{~m}^{2}$ and an average operating depth of $1.9 \mathrm{~m}$ during the treatment season. The WSP has an approximate volumetric and organic loading rate of $112 \mathrm{~m}^{3} / \mathrm{d}$ and $15 \mathrm{~kg} \mathrm{BOD} / \mathrm{ha} / \mathrm{d}$, respectively. The WSP is decanted in September. During the decant, wastewater is pumped from the WSP into a gravel channel. The outfall of the channel is a marine receiving environment approximately 2 $\mathrm{km}$ from the community.

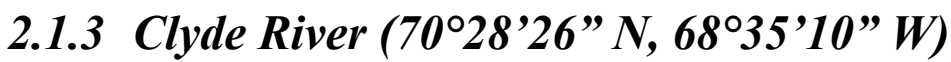

Clyde River is located on northern Baffin Island and has a population of approximately 1004 (Nunavut Bureau of Statistics 2013). Clyde River has a daily average temperature ( \pm standard deviation) of $-12.6 \pm 3.5^{\circ} \mathrm{C}$ with an average temperature during July and August of $4.7^{\circ} \mathrm{C}$ (Environment Canada 2014). Clyde River's system consists of a two cell WSP. The primary cell has an estimated surface area of $6000 \mathrm{~m}^{2}$ and an average operating depth of $1.1 \mathrm{~m}$ during the treatment season. The secondary cell has an estimated surface area of $15000 \mathrm{~m}^{2}$ and an average operating depth of $2.3 \mathrm{~m}$. The primary 
cell has an approximate volumetric and organic loading rate of $93 \mathrm{~m}^{3} / \mathrm{d}$ and $57 \mathrm{~kg}$ $\mathrm{BOD} / \mathrm{ha} / \mathrm{d}$, respectively. The system is designed to decant the secondary cell biennially, with wastewater being transferred from the primary to secondary cell yearly. However, due to operation issues, raw wastewater is occasionally discharged into the secondary cell. During the decant, wastewater is pumped from the secondary cell into an engineered vegetated filter strip. The outfall of the vegetated filter strip is a marine receiving environment approximately $1.2 \mathrm{~km}$ from the community.

\subsubsection{Grise Fiord $\left(76^{\circ} 25^{\prime} 3^{\prime \prime} N, 82^{\circ} 53\right.$ '38” W)}

Grise Fiord is located on southern Ellesmere Island and has a population of approximately 157 (Nunavut Bureau of Statistics 2013). Limited historical climate data is available for Grise Fiord. From 2011 to 2014 , the daily average temperature was $-13.3^{\circ} \mathrm{C}$ and the average daily temperature during July and August was $4.2^{\circ} \mathrm{C}$ (Environment Canada 2015). Grise Fiord's system consists of a single cell WSP with an estimated surface area of $4100 \mathrm{~m}^{2}$ and an estimated average operating depth during the treatment season of $1.5 \mathrm{~m}$. The WSP has an approximate volumetric and organic loading rate of 16 $\mathrm{m}^{3} / \mathrm{d}$ and $25 \mathrm{~kg} \mathrm{BOD} / \mathrm{ha} / \mathrm{d}$, respectively. The exact decant schedule varies and is highly weather dependent, but occurs during the ice-free season. During the decant, wastewater is pumped into a natural tundra wetland. The outfall of the wetland is a marine receiving environment approximately $620 \mathrm{~m}$ from the community. 


\subsubsection{Wastewater collection}

Due to continuous permafrost, all of the communities utilize vacuum trucks to collect wastewater directly from household storage tanks, as opposed to a conventional piped system. The wastewater generated by the communities is exclusively from domestic sources.

\subsection{Field Data Collection Timeline}

Field data collection occurred from June to September in 2011 through 2014. Due to logistical constraints associated with Northern research, such as weather, cost and lack of facilities, each site was not visited an equal number of times. Field visits fell into three ranges during the treatment season: start (June 15-July 7); middle (July 20-August 7); and end (August 25-September 15). The start of the treatment season coincides with the WSP thawing; often there is still limited ice coverage during this period. The end of the treatment season coincides with the decanting of the WSP prior to freezing. A summary of the sampling plan is shown in Table 1.

\subsection{Continuous Environmental Monitoring}

The WSP environment and ambient climatic conditions were continuously monitored in Kugaaruk, Pond Inlet and Clyde River. Dissolved oxygen, water temperature, conductivity, $\mathrm{pH}$, pressure and relative light were measured in the WSP throughout the treatment season using 6-Series and EXO in-situ multi-parameter sondes (YSI Inc., Yellow Springs, $\mathrm{OH}$ ), as well as $\mathrm{HOBO}$ temperature/light pendants (Onset Computer Corporation, Cape Cod, MA). Air temperature, barometric pressure, solar radiation and 
photosynthetically active radiation were measured using a weather station (Onset Computer Corporation, Cape Cod, MA) placed beside the WSP.

\subsection{Sample Collection and Analysis}

\subsubsection{Water Collection and Analysis}

Grab samples were collected using clean, Milli-Q rinsed, plastic sample bottles. WSP grab samples were taken from shore or from an inflatable boat using a sub-surface pole sampler (Environmental Remediation Equipment, Inc., Montreal, QC) or an acrylic bacon bomb sampler (Koehler Instrument Company, Inc., Bohemia, NY). Occasionally, surface samples were taken by hand.

As shown in Table 1, water sample analysis consisted of two sampling scenarios. The first was an analysis of total phosphorus (TP) and metals (aluminum, iron, manganese, and calcium) in the WSP. The second was an analysis of phosphorus species in the WSP, consisting of TP, total soluble phosphorus and soluble reactive phosphorus (SRP). A summary of the sampling locations and depths for each analysis is shown in Table 2. Raw wastewater was analyzed for TP and metals. Raw wastewater was not sampled at every sampling event shown in Table 1.

Samples were stored cooled and transported by aircraft to either Dalhousie University's Clean Water Laboratory in Halifax, Nova Scotia or Dalhousie University’s Northern Water Quality Laboratory in Iqaluit, Nunavut. Samples from Kugaaruk were analyzed at Taiga Environmental Laboratory, an accredited commercial lab located in Yellowknife, Northwest Territories. 
Samples were analyzed according to APHA and/or manufacturer specifications within their respective hold times.

SRP and TP were analyzed using the ascorbic acid method via $\operatorname{Hach}^{\circledR} \mathrm{TNT}^{\mathrm{TM}}$ or TNTplus $^{\mathrm{TM}}$ test kits. SRP samples were filtered prior to analysis using a $0.45 \mu \mathrm{m}$ polysulfone filter (GVS Life Sciences, Rome, ITA). Metals were digested with nitric acid according to APHA and analyzed using inductively coupled plasma mass spectrometry (XSeries 2 ICPMS, Thermo Fisher Scientific, Inc., Waltham, MA).

\subsubsection{Sediment Analysis}

Sediments were collected from Kugaaruk in 2013 and Pond Inlet in 2014. Sediments were not collected in Grise Fiord and Clyde River due to logistical travel constraints. Sediments were collected in Kugaaruk using custom built buckets. Three buckets were suspended in the water column approximately $3 \mathrm{~m}$ from the water surface using an anchor and buoy near the truck discharge location. The bucket had holes in the bottom with a non-woven geotextile glued over the top. This allowed for sediments to be retained by the geotextile while allowing water to flow through. The buckets were installed at the start of the treatment season and removed at the end of the treatment season. Upon removal, only one bucket was successfully retrieved. The remaining buckets either flipped or were placed in areas without considerable sedimentation. Sediments were collected in Pond Inlet in 2014 using an acrylic bacon bomb sampler (Koehler Instrument Company, Inc., Bohemia, NY). Single sediment samples were collected at the middle and end of the treatment season from four locations (inlet, outlet, center and the SE corner). Sediments were stored cooled and transported by aircraft to Dalhousie University's Clean 
Water Laboratory in Halifax, Nova Scotia and analyzed within 96 hours, with an average hold time less than 48 hours.

Sediments were analyzed for water content, TP, calcium, manganese, magnesium, iron and aluminum. Water content was analyzed according to APHA Standard Methods. Sediments were digested in $50 \%$ nitric acid at $105^{\circ} \mathrm{C}$. Digestion occurred for 3-4 hours, to the point where only inert material was remaining. Digested sediment was then analyzed for metals using inductively coupled plasma mass spectrometry (XSeries 2 ICPMS, Thermo Fisher Scientific, Inc., Waltham, MA). TP was also confirmed using the ascorbic acid method with acid persulfate digestion $\left(\mathrm{TNT}^{\mathrm{TM}}\right.$ or TNTplus ${ }^{\mathrm{TM}}$, Hach Company, Loveland, CO).

Phosphorus in the sediment was fractionated using the method described by Lukkari et al. (2007). The method is a further modification of the method developed by Psenner and Pucsko (1988) and modified by Jensen and Thamdrup (1993). It allows for the extraction of six phosphorus pools: loosely bound phosphorus, redox sensitive iron and manganese bound phosphorus, aluminum oxide or non-reducible iron bound phosphorus, calcium bound phosphorus and organic phosphorus. Organic phosphorus includes cellular components such as orthophosphate monoesters and diesters, phosphosaccharides, phytate as well as organically stored polyphosphates. Five different extractants were used in conjunction with filtration via $0.4 \mu$ m polycarbonate membranes (Nuclepore ${ }^{\mathrm{TM}}$, General Electric Healthcare Life Sciences, Little Chalfont, UK) to extract the pools. A summary of the extractants and their associated pools are shown in Table 3. Each extractant was analyzed for TP using the ascorbic acid method with acid persulfate digestion $\left(\mathrm{TNT}^{\mathrm{TM}}\right.$ or 
TNTplus $^{\mathrm{TM}}$, Hach Company, Loveland, CO). No modifications were made from the procedure described by Lukkari et al. (2007).

\subsection{Data Analysis}

Sampling events (WSP and raw wastewater) were tested for significance using analysis of variance or a Student's t-test depending on the number of events being evaluated. All of the sampling events were independent of one another. Assumptions of normality and equal variance were tested using the Shapiro-Wilk Normality Test and the F-test, respectively. Some sampling events failed $(\mathrm{p}<0.05)$ the normality and/or equal variance test, in which case, an appropriate test was chosen based on the findings of Skovlund and Fenstad (2001). For instance, if the sampling events had unequal variances, a non-normal distribution (heavy tailed) and unequal sample sizes, then the Welch's U test was performed. In cases of non-normality, the data was always heavy tailed, as opposed to skewed. A confidence level of $95 \%$ was used for determining significance of all tests. Statistical tests were conducted using Minitab 17 statistical software or R v3.2.2 statistical programming language (R Core Team 2015). 


\section{Results and Discussion}

\subsection{Temperature and $\mathrm{pH}$ Conditions}

A summary of the air and water temperatures and $\mathrm{pH}$ for Grise Fiord, Kugaaruk, Pond Inlet and Clyde River over the course of the treatment season is shown in Table 4. Kugaaruk, Pond Inlet and Clyde River experienced similar trends. Average air and water temperatures were consistently below $10^{\circ} \mathrm{C}$. Minimum temperatures below $0^{\circ} \mathrm{C}$ were experienced at the start and end of the treatment season. The $\mathrm{pH}$ was consistently near neutral with a range of 6.8 to 8.0. The temperature and $\mathrm{pH}$ followed a similar trend for the three sites. An example of the temperature and $\mathrm{pH}$ patterns over a sample year (Kugaaruk, 2013) is shown in Figure 1.

During the site visit to Grise Fiord, a very high $\mathrm{pH}$ (10.8) was observed, possibly due to an algae bloom occurring in the WSP. The average temperature was also higher, because samples were only taken over a few days during the warmest period of the treatment season, as opposed to over the entire treatment season. The water temperature $\left(14^{\circ} \mathrm{C}\right)$ was similar to the maximum temperatures at the other research sites.

\subsection{Total Phosphorus Results for Kugaaruk, Pond Inlet, Grise Fiord and Clyde River}

The treatment performance for each system, with respect to TP, was highly variable. WSP effluent concentrations ranged from $3.5 \mathrm{mg} \mathrm{P} / \mathrm{L}$ to $12.2 \mathrm{mg} \mathrm{P} / \mathrm{L}$. A summary of the TP concentrations observed for each system is shown in Figure 3. 
Raw wastewater concentrations were not taken consistently and are not available for each year. Since wastewater in each community is solely from domestic sources, it was assumed that raw wastewater did not change significantly from year to year. Therefore, raw wastewater data were pooled for each site. This assumption was tested using data from Pond from $2012(n=17)$ and $2013(n=8)$. The mean raw wastewater concentration for each year was confirmed to not be significantly different $(\mathrm{p}>0.05)$. There was variation in the raw wastewater concentrations between each site (Figure 3). At $11.4 \mathrm{mg}$ $\mathrm{P} / \mathrm{L}$, the lowest average concentration was observed in Kugaaruk. Pond Inlet had the highest raw wastewater concentration at $15.9 \mathrm{mg} \mathrm{P} / \mathrm{L}$. With the exception of Grise Fiord, a high variability was observed for the raw wastewater concentrations. The low variability in Grise Fiord is attributed to a smaller sample size compared to other sites that were sampled multiple times per year for 2-3 years. Overall the concentrations were much higher than what is typically observed in southern Canada (below the $60^{\text {th }}$ parallel) where TP concentrations in raw domestic wastewater of $7 \mathrm{mg} \mathrm{P} / \mathrm{L}$ (deemed medium strength) are typical (Tchobanoglous et al. 2003). This discrepancy is due to a low per capita water usage in Nunavut. The average water consumption in the four research communities was approximately $87 \mathrm{~L}$ per capita per day whereas, in southern Canada, the average usage is $274 \mathrm{~L}$ per capita per day (Environment Canada, 2011). In effect, the low water consumption concentrates wastewater constituents.

In Kugaaruk, reduction was highly variable (Figure 3a). In 2012, TP concentrations at the start and end of the treatment season were found to be significantly different $(\mathrm{p}<0.05)$. Throughout the treatment season, TP concentrations decreased from 8.2 to $6.9 \mathrm{mg} \mathrm{P} / \mathrm{L}$. TP concentrations at the start and end of the treatment season were significantly different 
from the raw wastewater TP concentrations $(\mathrm{p}<0.05)$. In 2013, TP concentrations were also significant different $(\mathrm{p}<0.05)$ at the start and end of the treatment season. However, during the 2013 treatment season, TP concentrations increased from 7.0 to $9.8 \mathrm{mg} / \mathrm{L}$. By the end of the 2013 treatment season TP concentrations were not significantly different than the raw wastewater TP concentration $(\mathrm{p}>0.05)$. The reason for the variable treatment between years is unknown. However, it could be due to several factors such as increased rainfall in 2012 or variability in decant volumes leading to longer retention times.

In Pond Inlet, some reductions in TP concentrations were seen in the WSP relative to the raw wastewater (Figure 3b). TP concentrations throughout the treatment season (20122014) were lower than the raw wastewater TP concentration $(p<0.05)$. However, TP concentrations at the end of the treatment season were either higher $(2012,2013 ; \mathrm{p}<0.05)$ or not significantly different $(2014, \mathrm{p}>0.05)$ from TP concentrations at the start of the treatment season. This shows that little or no additional treatment was occurring during the summer treatment season. At the end of the treatment season, TP concentrations ranged from $9.8 \mathrm{mg} \mathrm{P} / \mathrm{L}$ (2012) to $12.2 \mathrm{mg} \mathrm{P} / \mathrm{L}$ (2014). The reason for lower TP concentrations at the start of the treatment season in 2012 and 2013 is unknown; however it could be due to several factors including increased dilution from snowmelt.

Clyde River was the only 2 cell WSP studied (Figure 3c). TP concentrations in the primary cell at the start of each treatment season were significantly different for each year $(\mathrm{p}<0.05)$. TP concentrations ranged from 7.8 (2012) to $13.5 \mathrm{mg} \mathrm{P} / \mathrm{L}(2014)$. In 2014, the TP concentration in the primary cell at the start of the treatment season was not significantly different from the raw wastewater TP concentration ( $p>0.05)$. In 2012 and 2013, TP concentrations were lower than the raw wastewater concentration $(p<0.05)$. At 
the end of the treatment season TP concentrations in the primary cell either increased $(2012, p<0.05)$ or decreased $(2013,2014 ; \mathrm{p}<0.05)$ compared to TP concentrations at the start of the treatment season. In all years, TP concentrations at the end of the treatment season were lower than the raw wastewater TP concentrations $(\mathrm{p}<0.05)$. There was much less variation in TP concentrations in the primary cell at the end of the treatment season compared to the start of the treatment season, however concentrations were significantly among years $(\mathrm{p}<0.05)$. TP concentrations ranged from $8.3 \mathrm{mg} \mathrm{P} / \mathrm{L}(2012)$ to $9.4 \mathrm{mg} \mathrm{P} / \mathrm{L}$ (2013). Over three years of measurement, the primary cell was able to achieve a mean removal of $40 \%$. TP concentrations in the secondary cell were lower than in the primary cell $(\mathrm{p}<0.05)$. However, there was minimal reduction $(14 \%)$ over the treatment season. The mean difference in TP concentrations at the end of the treatment season between the primary and secondary cell was $33 \%$. Overall, the system was able to achieve a mean removal of $60 \%$.

Inter-seasonal comparisons could not be made in Grise Fiord (Figure 3d). However, at $3.5 \mathrm{mg}$ P/L, the lowest WSP TP concentration was observed in Grise Fiord. When this sample was taken, an abundant population of algae was observed in the WSP. It is hypothesized that the increased removal efficiency was due to a combination of two mechanisms. The first is direct biological uptake of phosphorus by algae. The second is chemical precipitation of phosphorus with calcium facilitated by an increase in the WSP $\mathrm{pH}$ caused by the algae bloom. Algae blooms cause $\mathrm{pH}$ increases by consuming carbon dioxide during photosynthesis. A pH of 10.8 was observed in the WSP, which is ideal for calcium phosphate formation. Moutin et al. (1992) found that $93 \%$ of phosphate deposits in a high rate algal pond with natural calcium concentrations ranging from $50-150 \mathrm{mg} / \mathrm{L}$ 
were calcium phosphate precipitates. The system studied by Moutin et al. (1992) had a $\mathrm{pH}$ of 8.7 and was only able to achieve a phosphorus removal of $\sim 25 \%$. Calcium concentrations in the raw wastewater and WSP in Grise Fiord were $18.2 \pm 0.5 \mathrm{mg} / \mathrm{L}$ and $21.1 \pm 4.9 \mathrm{mg} / \mathrm{L}$, respectively. Therefore it is possible that some of the TP removal in Grise Fiord could be attributed to calcium precipitation. Understanding the exact removal mechanisms in Grise Fiord, as well as the long-term phosphorus storage in the sediment layer, requires further research.

In their current configuration, the WSPs are unable to consistently achieve high removals of phosphorus. Single cell WSPs in Kugaaruk and Pond Inlet achieved removal efficiencies of $27 \%$ and $31 \%$, respectively. Higher removals were seen in the Grise Fiord single cell WSP in 2011; however, these results were likely a function of algae growth and favourable climate conditions that were not indicative of an average treatment season. It does show that if WSPs could be reconfigured to optimize algae growth, high percent removals could be achieved in a passive system. The two cell configuration studied in Clyde River achieved removal efficiencies of $60 \%$, performing much better than the other multi-year study sites (Kugaaruk and Pond Inlet). Ultimately, TP concentrations in the effluent from the studied WSPs were comparable to typical medium strength raw wastewaters $(7 \mathrm{mg} \mathrm{P} / \mathrm{L})$ in southern Canada.

\subsection{Soluble Reactive Phosphorus Results for Kugaaruk and Pond Inlet}

Phosphorus species were analyzed in Kugaaruk in 2013 and Pond Inlet in 2014. Analyses revealed that SRP was the predominant aqueous species. Results from each site showed 
similar trends. SRP represented $81 \%$ of TP in both Kugaaruk and Pond Inlet. A summary of the TP and SRP concentrations in Kugaaruk and Pond Inlet are shown in Table 5.

Similar to TP concentrations, SRP concentrations in Kugaaruk increased from $5.6 \mathrm{mg}$ P/L to $8.1 \mathrm{mg} \mathrm{P} / \mathrm{L}(\mathrm{p}<0.05)$ over the course of the treatment season. SRP concentrations in Pond Inlet stayed constant; no significant difference $(\mathrm{p}>0.05)$ between concentrations at the start, middle and end of the treatment season was observed.

The large concentration of SRP could be advantageous, as it represents the fraction of TP that could be removed with additional treatment such as coagulation or WSP reconfiguration to optimize algae growth. If WSPs could be optimized for SRP removal, it is expected that effluent TP concentrations equal to the soluble unreactive phosphorus $(<2 \mathrm{mg} \mathrm{P} / \mathrm{L})$ could be achieved. Considerations would have to be made to ensure that algae can be removed from the system through settling, filtration or another process. The re-release of phosphorus from settled algae under the extreme conditions experienced in these WSPs requires further investigation.

\subsection{Sediment Analysis Results for Kugaaruk and Pond Inlet}

The results of the sediment analysis from Kugaaruk and Pond Inlet showed that sediment phosphorus concentrations varied spatially and temporally. Sediments were not collected in Clyde River and Grise Fiord due to logistical travel constraints. A summary of the phosphorus concentration for each fraction is shown in Table 6.

Only one sediment sample was taken from Kugaaruk (Table 6). The sample had a phosphorus concentration of $2.84 \mathrm{mg} \mathrm{P} / \mathrm{g}$ dry sediment. Organic phosphorus $(49 \%)$ was 
the largest fraction followed by phosphorus bound to redox sensitive iron and manganese oxides $(21 \%)$ and phosphorus bound to aluminum and non-reducible iron oxides (18\%). Calcium bound phosphorus was the smallest fraction (2\%).

Samples were taken from the Pond Inlet WSP at four points: the inlet, outlet, center and the SE corner (Table 6). The center of the WSP had the highest sediment phosphorus concentration at both the mid point and end of the treatment season. At the inlet, center and SE corner, sediment phosphorus concentrations increased through the treatment season. However, at the outlet, concentrations decreased. This difference is likely due to sample variation. Fractionation results followed a similar trend to Kugaaruk. The largest fraction was consistently either organic phosphorus or phosphorus bound to aluminum and non-reducible iron oxides. Phosphorus bound to redox sensitive iron and manganese oxides were the third largest fraction in all of the samples. An analysis in Pond Inlet of the metals concentration in raw wastewater found approximately $8 \mathrm{mg} / \mathrm{L}$ of calcium, 1.0 $\mathrm{mg} / \mathrm{L}$ of iron, $2.8 \mathrm{mg} / \mathrm{L}$ of aluminum and $0.05 \mathrm{mg} / \mathrm{L}$ of manganese. Drinking water in Pond Inlet comes from a water reservoir that fills from either snowmelt water or from water pumped from a nearby stream. Surface water in Nunavut is generally considered to be pristine and therefore disinfection is the only treatment provided. Metals present in the wastewater would have to come from this low impacted water source or through dissolution of premise plumbing.

Sediments from the Pond Inlet WSP had a pooled mean of $4.42 \pm 1.65$ and $5.43 \pm 3.20$ $\mathrm{mg} \mathrm{P} / \mathrm{g}$ dry sediment at the middle and end of the treatment season, respectively. These concentrations were not significantly different from one another $(p>0.05)$. 
The sediment sample from Kugaaruk had a relatively low phosphorus concentration compared to samples from Pond Inlet (Table 6). The Kugaaruk sample was collected from within the water column, as opposed to from the bottom sludge layer where the Pond Inlet sample were taken. Therefore, the Kugaaruk sample represents sediments deposited in one treatment season, as opposed to long-term sediment consolidation and storage.

At both sites, calcium bound phosphorus made up of a relatively small portion of the sediment phosphorus. Therefore, is it expected that while there are calcium ions present, the WSP $\mathrm{pH}$ is limiting calcium phosphate formation. The average $\mathrm{pH}$ observed in Pond Inlet and Kugaaruk WSP was $7.4 \pm 0.2$ with a maximum value of 8.0. Diaz et al. (1994) found that phosphorus solubility was not affected at a $\mathrm{pH}$ less than 9 when calcium concentrations were below $50 \mathrm{mg} / \mathrm{L}$.

The most promising removal mechanisms were biological and precipitation/adsorption with iron (redox sensitive or non-reducible) or aluminum. These mechanisms were able to occur in passive WSPs and most importantly, the particulate was able to persist in sediment layer resulting in long-term storage. Three possible options for system modification in order to optimize these removal mechanisms are: (1) the WSP could be reconfigured to increase surface area to help support algae growth, or (2) iron or aluminum could be added to increase chemical precipitation or (3) an integrated approach combining both strategies could be used. While these strategies could increase phosphorus removal, they are not without disadvantages. WSP reconfiguration would have significant capital costs and land requirements. Chemical addition would also have 
associated capital and operating costs. It would also increase sludge production, therefore requiring sludge dredging and disposal.

\section{Conclusions}

Research in these Arctic communities provided a unique set of challenging conditions including weather and facility constraints. However, after four years of field monitoring, the following conclusions were made:

- Total phosphorus removal in Kugaaruk, Pond Inlet and Clyde River ranged from 14 to $63 \%$. The average effluent concentrations for Kugaaruk, Pond Inlet and Clyde River were 8.4, 11.2 and 5.9 $\mathrm{mg}$ P/L, respectively. Even at the highest percent removal (63\%), effluent concentrations were high relative to concentrations seen in southern Canada. High effluent concentrations are partly due to elevated raw wastewater concentrations attributed to low per capita water usage.

- Grise Fiord exhibited much higher removal (76\%); however, this was only observed once and was not representative of the rest of the data gathered. Therefore, the results in Grise Fiord represent an opportunity for further research rather than an expected result for other systems.

- Soluble reactive phosphorus represented $81 \%$ of the total phosphorus present in the Kugaaruk and Pond Inlet waste stabilization pond. Therefore, it is expected that high phosphorus removal could be achieved if a new treatment design, such 
as coagulation addition or WSP reconfiguration, was implemented in order to target this fraction.

- Sediment analysis in Kugaaruk and Pond Inlet show that organic phosphorus and phosphorus bound to iron or aluminum represented the highest fraction of sediment phosphorus. These two fractions represented between 88 and $97 \%$ by dry mass. Therefore, these removal mechanisms should be further examined in order to determine if they could be optimized for increased removal.

\section{Acknowledgements}

We would like to thank the people of the communities of Grise Fiord, Pond Inlet, Kugaaruk and Clyde River. Special thanks to the Nunavut Research Institute as well as Tristan Goulden, Andrew Sinclair, Erin Mentink, Justine Lywood, Mark Greenwood, Jenny Hayward, Evan Bridson-Pateman, Kiley Daley, Joanna Poltarowicz, Yannan Huang, Jessica LeNoble, Meggie Letman, Kira Krumhansl, Amy Jackson and Amy McClintock for laboratory and field assistance. Support for this project was provided by the Government of Nunavut and NSERC.

\section{References}

Canadian Council of Ministers of the Environment (CCME) 2009. Canada-wide Strategy for the Management of Municipal Wastewater Effluent. Available from: $<$ http://www.ccme.ca/assets/pdf/cda_wide_strategy_mwwe_final_e.pdf $>$. [January 26, $2015]$. 
Diaz, O.A., Reddy, K.R., and Moore Jr., P.A. 1994. 'Solubility of inorganic phosphorus in stream water as influenced by $\mathrm{pH}$ and calcium concentration', Water Res., vol. 28, no. 8 , pp. $1755-1763$.

Environment Canada 2011. 2011 Municipal Water Use Report. Available from: $<$ https://www.ec.gc.ca/Publications/B77CE4D0-80D4-4FEB-AFFA0201BE6FB37B/2011-Municipal-Water-Use-Report-2009-Stats_Eng.pdf>. [December 10, 2014].

Environment Canada 2014. 1981-2010 Climate Normals \& Averages. Available from: $<$ http://climate.weather.gc.ca/climate_normals/index_e.html $>$. [December 10, 2014].

Environment Canada 2015. Historical Weather Data (Station: Grise Fiord Climate). Available from: < http://climate.weather.gc.ca/index_e.html\#access $>$. [December 15, 2015].

Goltermann, H.L. 1996. 'Fractionation of sediment phosphate with chelating compounds: a simplification, and comparison with other methods', Hydrobiologia, vol. 335 , pp. $87-95$.

Grönlund, E., Hanaeus, J., Johansson, E., and Falk, S. 2010. 'Performance of an experimental wastewater treatment high-rate algal pond in subarctic climate', Water Environ. Res., vol. 82, no. 9, pp. 830-839.

Hanaeus, J. 1987. 'Swedish field experiences with chemical precipitation in stabilization ponds', Can. J. Civ. Eng., vol. 14, pp. 33-40. 
Hanaeus, J., Grönlund, E., and Johansson, E. 2010. 'Seasonal operation of ponds for chemical precipitation of wastewater', J. Cold Reg. Eng., vol. 24, no. 4, pp. 98-111.

Heaven, S., Lock, A.C., Pak, L.N., and Rspaev, M.K. 2003. 'Waste stabilization ponds in extreme continental climates: A comparison of design methods from the USA, Canada, northern Europe and the former Soviet Union', Water. Sci. Technol., vol. 48, no. 2 , pp. 25-33.

Jensen, H.S., and Thamdrup, B. 1993. 'Iron-bound phosphorus in marine sediments as measured by bicarbonate-dithionite extraction', Hydrobiologia, vol. 253, pp. 47-59.

Krumhansl, K.A., Krkosek, W.H., Greenwood, M., Ragush, C., Schmidt, J., Grant, J., Barrell, J., Lu, L., Lam, B., Gagnon, G.A., and Jamieson, R.C. 2015. 'Assessment of arctic community wastewater impacts on marine benthic invertebrates', Environ. Sci. Technol., vol. 49, no. 2, pp. 760-766.

Lukkari, K., Hartikainen, H., and Leivuori, M. 2007. 'Fractionation of sediment phosphorus revisted. I: Fractionation steps and their biogeochemical basis', Limnol. Oceanogr., Methods, vol. 5, pp. 433-444.

Miyachi, S., Kanai, R., Mihara, S., Miyachi, S., and Aoki, S. 1964. 'Metabolic roles of inorganic polyphosphates in Chlorella cells', Biochim. Biophys. Acta., vol. 93, no. 3, pp. 625-634.

Moutin, T., Gal, J.Y., Halouani, H.E.1., Picot, B., and Bontoux, J. 1992, 'Decrease of phosphate concentration in a high rate pond by precipitation of calcium phosphate: theoretical and experimental results', Water Res., vol. 26, no. 11, pp. 1445-1450. 
Nunavut Bureau of Statistics 2013. Population Estimates, July 1, 2013. Available from: $<$ http://www.stats.gov.nu.ca/Publications/Popest/Population/Population\%20Estimates \%20Report,\%20July\%201,\%202013.pdf>. [November 24, 2014].

Peng, J., Wang, B., Song, Y., Yuan, P., and Liu, Z. 2007. 'Adsorption and release of phosphorus in the surface sediment of wastewater stabilization pond', Ecol. Eng., vol. 31, pp. $92-97$.

Psenner, R., and Pucsko, R. 1988. 'Phosphorus fractionation: advantages and limits of the method for the study of sediment P origins and interactions', Arch. Hydrobiol. Beih. Ergebn. Limnol., vol. 30, pp. 43-59.

R Core Team 2015, R: A Language and Environment for Statistical Computing. R Foundation for Statistical Computing, Vienna, Austria. Available from: $<$ http://www.R-project.org $>$.

Skovlund, E., and Fenstad, G.U. 2001. 'Should we always choose a nonparametric test when comparing two apparently nonnormal distributions?', J. Clin. Epidemiol., vol. 54, pp. 86-92.

Tchobanoglous, G., Burton, F.L., and Stensel, H.D. 2003. Wastewater Engineering: Treatment and Reuse, $4^{\text {th }}$ edn. McGraw-Hill, New York.

Wilsenach, J.A., Schuurbiers, C.A.H., and van Loosdrecht, M.C.M. 2007. 'Phosphate and potassium recovery from source separated urine through struvite precipitation', Water Res., vol. 41, no. 2, pp. 458-466. 
Figure 1: Locations of the four communities (Kugaaruk, Grise Fiord, Pond Inlet and Clyde River) in Nunavut where waste stabilization pond sampling took place between 2011 and 2014.

Figure 2: Air temperature, water temperature and pH measurement collected in the Kugaaruk WSP in 2013. The grey boxes refer to the different periods of the treatment season.

Figure 3: Total phosphorus concentration found for raw wastewater (Raw) and in waste stabilization ponds during the summer treatment season at (a) Kugaaruk, (b) Pond Inlet, (c) Clyde River and (d) Grise Fiord. Data are means with $95 \%$ confidence intervals and the number of samples is shown at the bottom of each bar. 


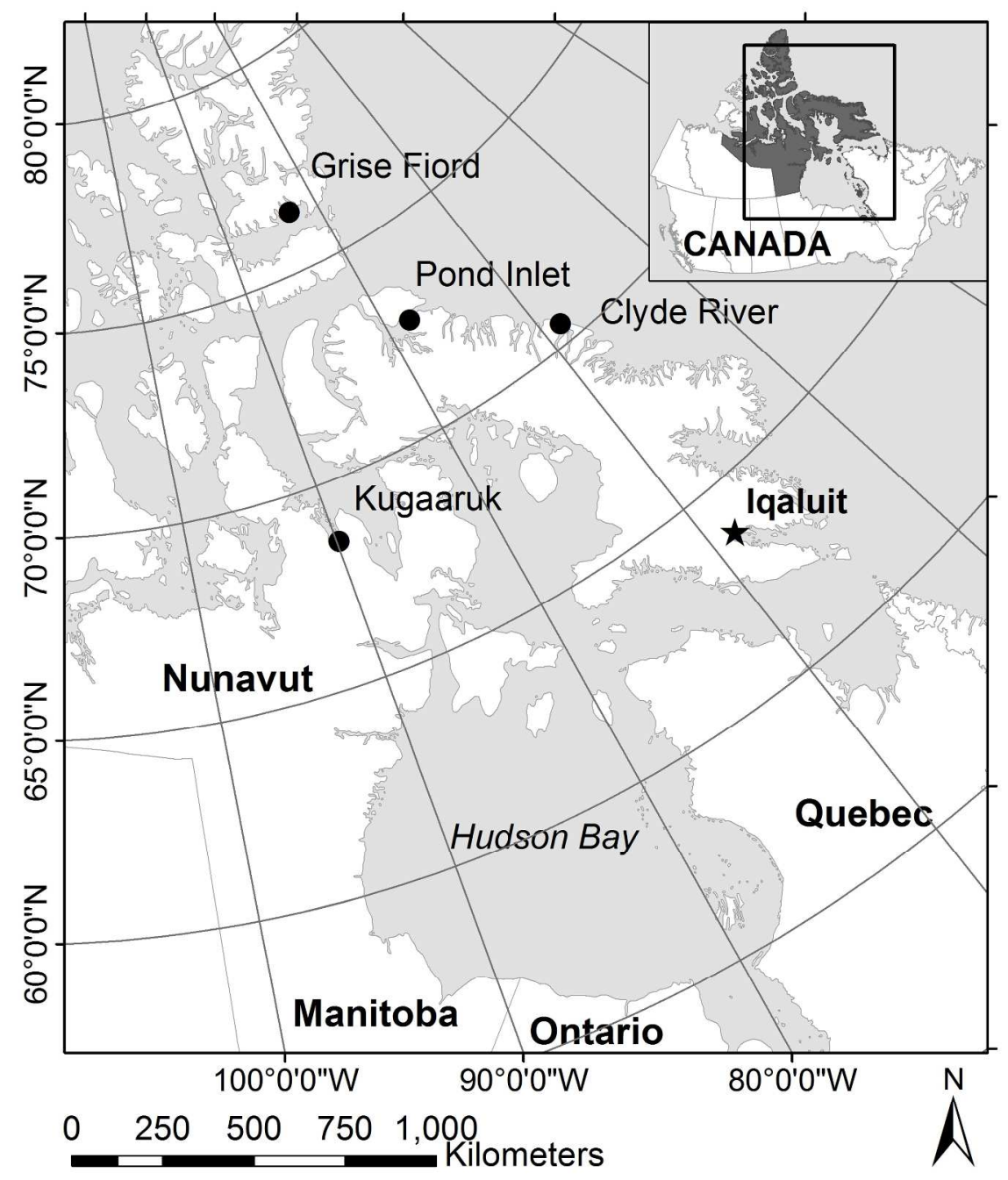

$215 \times 279 m m(300 \times 300$ DPI $)$ 


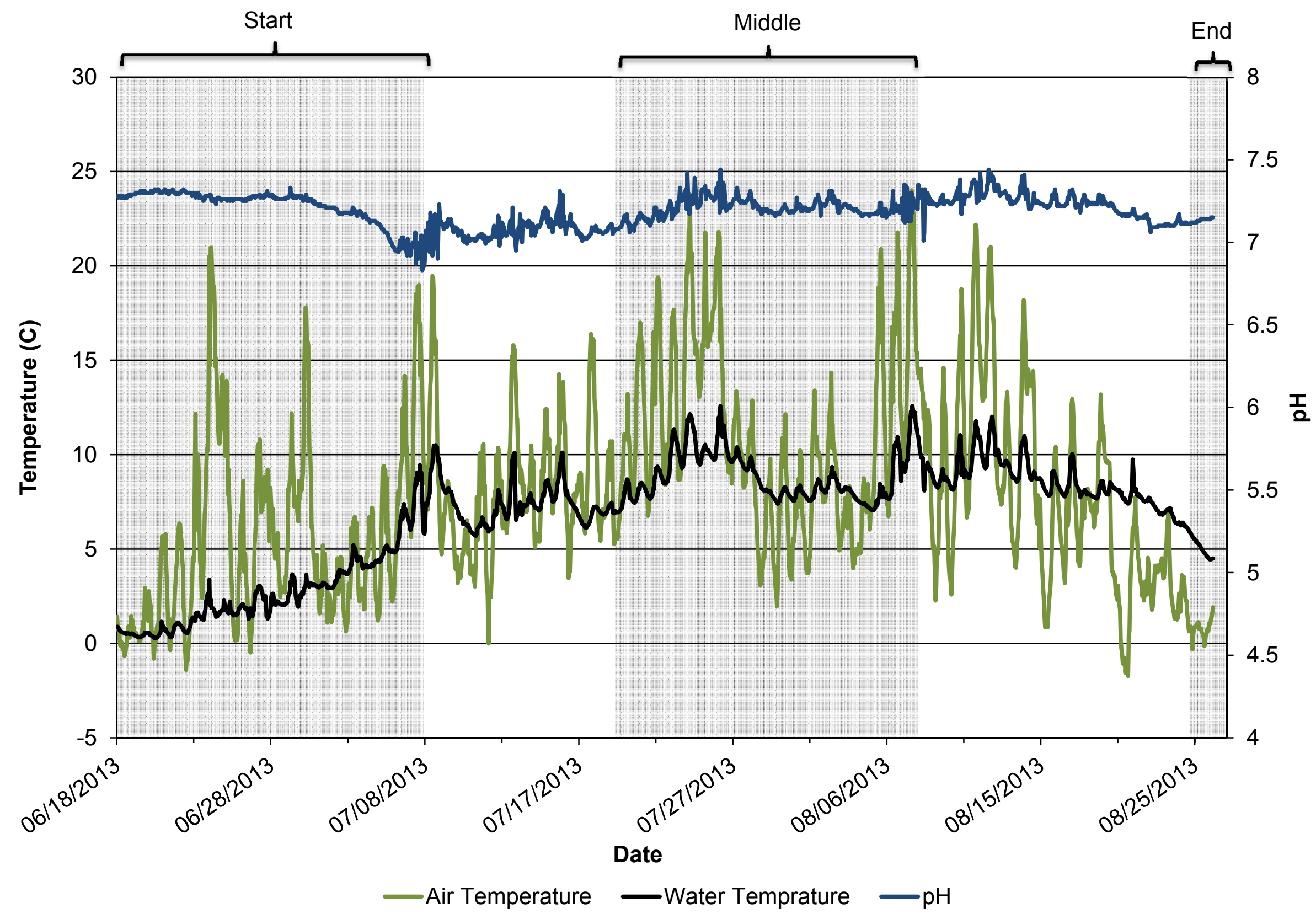


a)

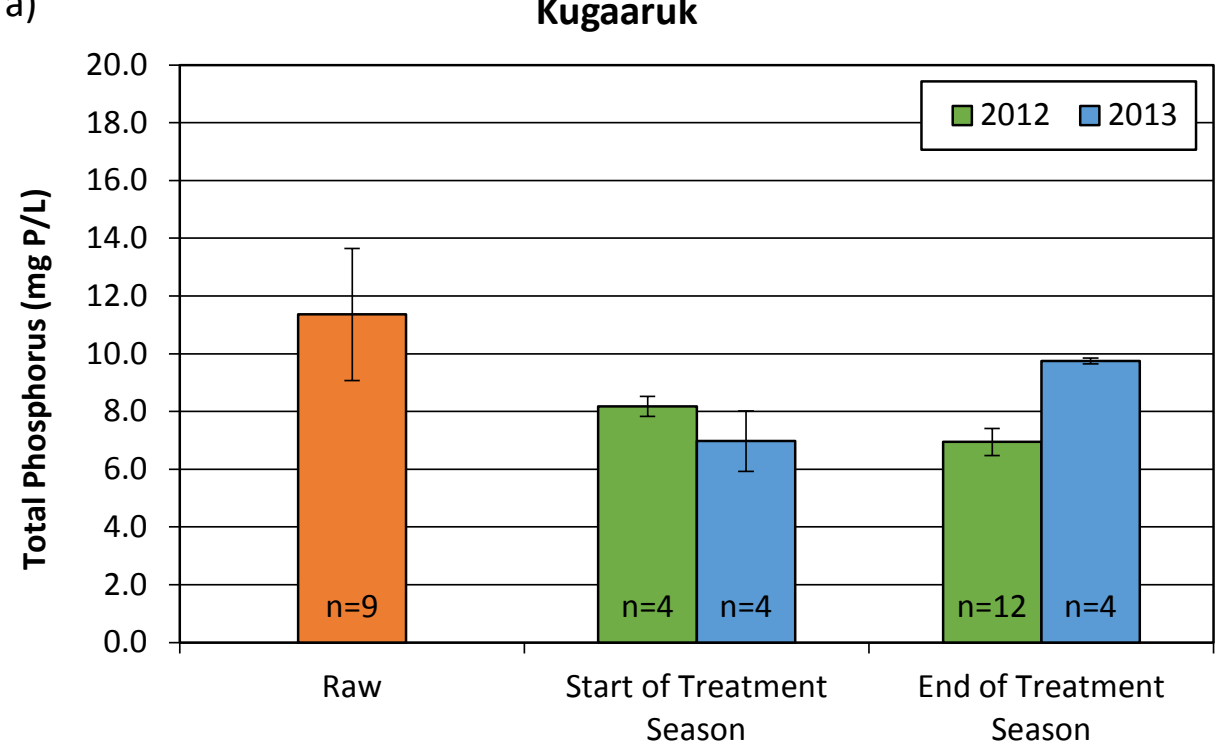

c)

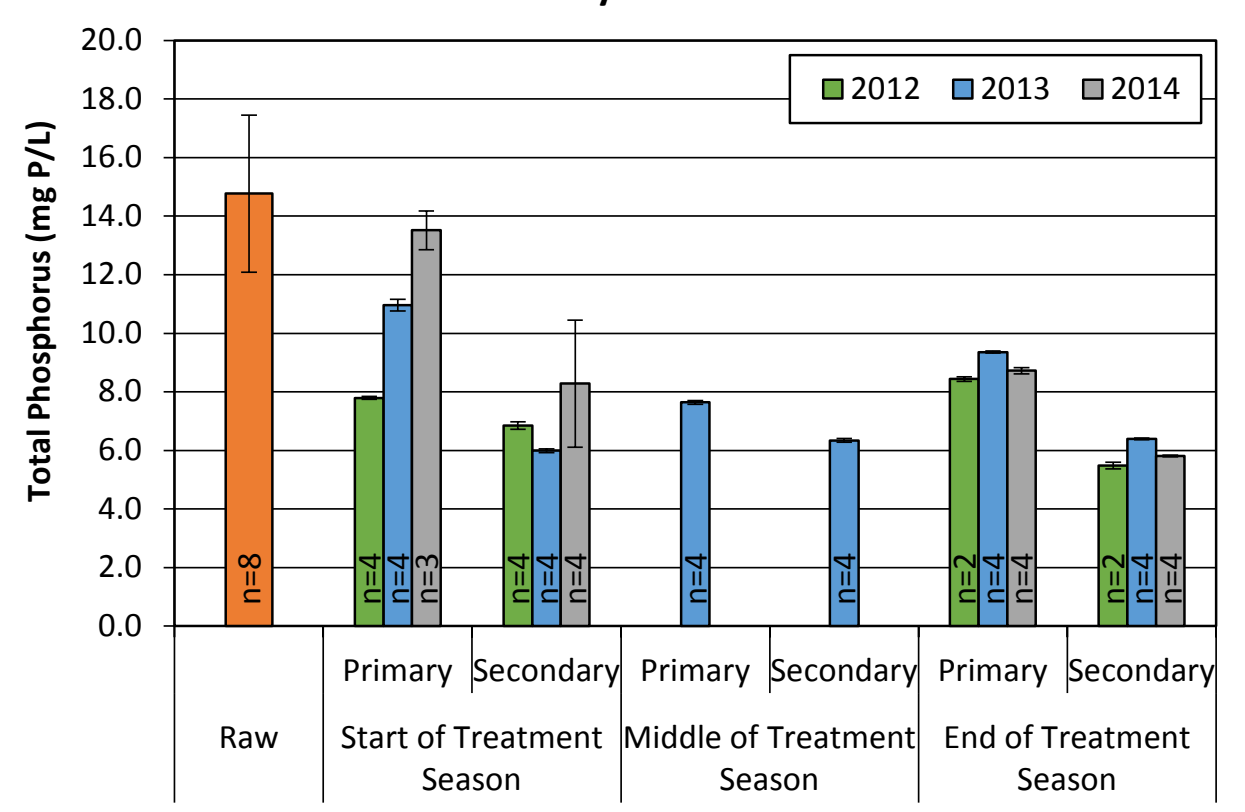

b)

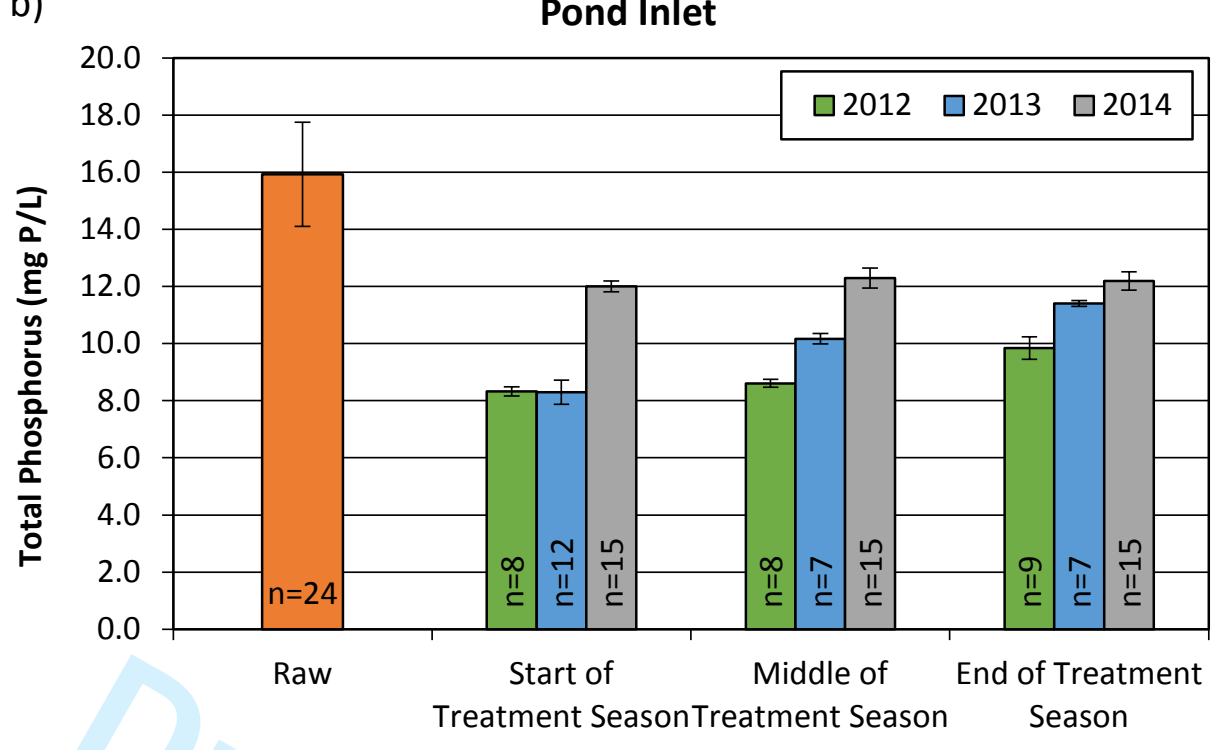

d)

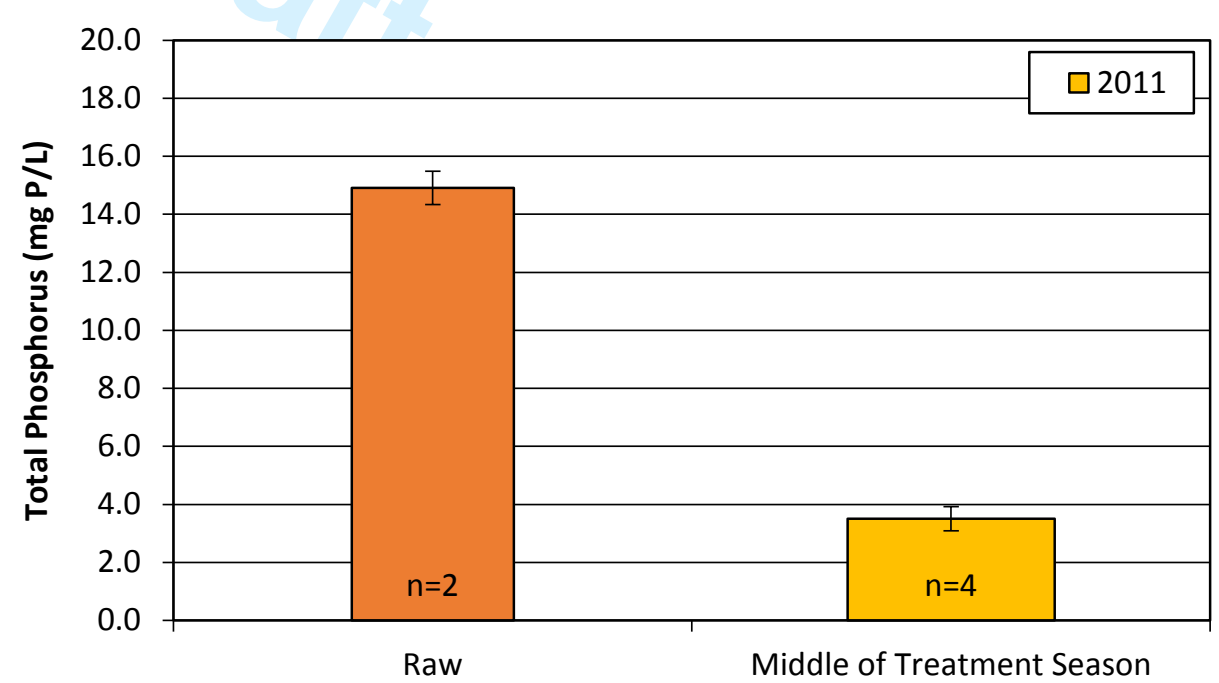


Table 1: Sampling plan for wastewater systems in four Arctic communities.

\begin{tabular}{|c|c|c|c|c|c|c|c|c|c|c|c|c|}
\hline & \multicolumn{3}{|c|}{2011} & \multicolumn{3}{|c|}{2012} & \multicolumn{3}{|c|}{2013} & \multicolumn{3}{|c|}{2014} \\
\hline & Start & Middle & End & Start & Middle & End & Start & Middle & End & Start & Middle & End \\
\hline Grise Fiord & & + & & & & & & & & & & \\
\hline Pond Inlet & & & & + & + & + & + & + & + & $+, \mathrm{o}, \S$ & $+, \mathrm{o}, \S$ & $+, \mathrm{o}, \S$ \\
\hline Clyde River & & & & + & & + & + & + & + & + & & + \\
\hline Kugaaruk & & & & + & & + &,$+ \mathrm{o}$ & & $+, \mathrm{o}, \S$ & & & \\
\hline
\end{tabular}

$+\quad$ Total Phosphorus, metal parameters (Aluminum, iron, manganese, calcium)

o Phosphorus Species Analysis: Total Phosphorus, Total Soluble Phosphorus, Soluble Reactive Phosphorus

$\S \quad$ Sediment Analysis

Note: Start (June 15-July 7), middle (July 20-August 7) and end (August 25-September 15) refer to the time during the treatment season, with start corresponding to the WSP thaw and the end corresponding to the WSP freezing 
Table 2: Summary of waste stabilization pond sampling locations and depths for each analysis

\begin{tabular}{|c|c|c|c|}
\hline Location & Sampling Locations & $\begin{array}{c}\text { Total Phosphorus and Metals } \\
\text { Analysis Depths }\end{array}$ & $\begin{array}{c}\text { Phosphorus Species Analysis } \\
\text { Depths }\end{array}$ \\
\hline Grise Fiord & 4 (corners) & Surface Only & \\
\hline Pond Inlet & 5 (corners + middle) & Surface and Bottom & $\begin{array}{c}\text { Corners }-0,50, \text { and } 100 \mathrm{~cm} \\
\text { Middle }-0,50,100 \text { and } 250 \mathrm{~cm}\end{array}$ \\
\hline Clyde River & 2 in each cell & Surface and Bottom & \\
\hline Kugaaruk & 5 (corners + middle) & Surface and Bottom & Surface and Bottom \\
\hline
\end{tabular}


Table 3: Summary of the extractants used and their associated pools of phosphorus, as described by Lukkari et al. (2007)

\begin{tabular}{|l|l|}
\hline Extractant & Pool \\
\hline $0.46 \mathrm{M}$ sodium chloride & $\begin{array}{l}\text { Loosely bound, pore water phosphorus, } \\
\text { organic phosphorus }\end{array}$ \\
\hline $\begin{array}{l}\text { 0.11 M sodium dithionite } \\
\text { solution buffered with 0.11 M } \\
\text { sodium bicarbonate }\end{array}$ & $\begin{array}{l}\text { Redox sensitive iron and manganese } \\
\text { bound phosphorus, organic phosphorus }\end{array}$ \\
\hline $0.1 \mathrm{M}$ sodium hydroxide & $\begin{array}{l}\text { Aluminum and non-reducible iron bound } \\
\text { phosphorus, organic phosphorus }\end{array}$ \\
\hline $0.5 \mathrm{M}$ hydrochloric acid & $\begin{array}{l}\text { Calcium bound phosphorus, organic } \\
\text { phosphorus }\end{array}$ \\
\hline $1 \mathrm{M}$ hydrochloric acid & Refractory organic phosphorus \\
\hline
\end{tabular}


Table 4: A summary of mean ( \pm standard deviation), maximum and minimum air temperatures, water temperatures and pH for WSPs located in Kugaaruk, Pond Inlet and Clyde River during the treatment season (June-September).

\begin{tabular}{|c|c|c|c|c|c|c|c|c|c|c|c|}
\hline \multirow{2}{*}{\multicolumn{2}{|c|}{ Site }} & \multirow{2}{*}{ Year } & \multicolumn{3}{|c|}{ Air Temperature $\left({ }^{\circ} \mathrm{C}\right)$} & \multicolumn{3}{|c|}{ Water Temperature $\left({ }^{\circ} \mathrm{C}\right)$} & \multicolumn{3}{|c|}{$\mathrm{pH}$} \\
\hline & & & Average & Max & Min & Average & Max & Min & Average & Max & Min \\
\hline \multicolumn{2}{|l|}{ Grise Fiord } & 2011 & & & & $14.2 \pm 1.0^{1}$ & & & $10.8 \pm 0.1^{1}$ & & \\
\hline \multirow{2}{*}{\multicolumn{2}{|c|}{ Kugaaruk }} & 2012 & $8.9 \pm 4.4$ & 24.3 & -3.2 & $7.8 \pm 0.9$ & 10 & 4.1 & $7.6 \pm 0.1$ & 7.8 & 7.4 \\
\hline & & 2013 & $7.9 \pm 5.2$ & 24.0 & -1.7 & $6.7 \pm 3.0$ & 12.6 & 0.3 & $7.2 \pm 0.1$ & 7.4 & 6.8 \\
\hline \multirow{3}{*}{\multicolumn{2}{|c|}{ Pond Inlet }} & 2012 & $6.8 \pm 3.5$ & 17.9 & -1.5 & $8.4 \pm 1.5$ & 12.6 & 5.2 & $7.6 \pm 0.1$ & 7.8 & 7.2 \\
\hline & & 2013 & $6.4 \pm 3.5$ & 18.3 & -2.0 & $7.3 \pm 3.7$ & 14.8 & 1.0 & $7.5 \pm 0.1$ & 7.7 & 7.1 \\
\hline & & 2014 & $5.9 \pm 4.1$ & 18.3 & -5.6 & $8.5 \pm 2.2$ & 13.6 & 4.0 & $7.8 \pm 0.1$ & 8.0 & 7.6 \\
\hline \multirow[t]{6}{*}{ Clyde River } & Primary & \multirow{2}{*}{2012} & \multirow{2}{*}{$7.0 \pm 3.5$} & \multirow{2}{*}{22.3} & \multirow{2}{*}{-0.9} & $3 \sqrt{20}$ & & & $7.2^{2}$ & & \\
\hline & Secondary & & & & & $8.6 \pm 2.8$ & 13.3 & 4.0 & $7.4^{2}$ & & \\
\hline & Primary & \multirow{2}{*}{2013} & \multirow{2}{*}{$5.2 \pm 3.3$} & \multirow{2}{*}{15.6} & \multirow{2}{*}{-1.4} & $7.9 \pm 3.4$ & 17.5 & 0.6 & $7.5 \pm 0.1$ & 7.7 & 7.2 \\
\hline & Secondary & & & & & $8.1 \pm 2.5$ & 13.9 & 2.7 & $7.4 \pm 0.1$ & 7.6 & 7.2 \\
\hline & Primary & \multirow{2}{*}{2014} & \multirow{2}{*}{$6.2 \pm 3.6$} & \multirow{2}{*}{18.0} & \multirow{2}{*}{-1.4} & $7.2 \pm 3.7$ & 16.4 & 0.0 & $7.3 \pm 0.2$ & 7.6 & 6.9 \\
\hline & Secondary & & & & & $7.9 \pm 2.7$ & 12.7 & 0.7 & $7.4 \pm 0.1$ & 8.0 & 7.3 \\
\hline
\end{tabular}

Spot samples $(\mathrm{n}=8)$

${ }^{2}$ Spot samples $(\mathrm{n}=2)$ 
Table 5: Total and soluble reactive phosphorus concentrations at various points in the treatment systems in Kugaaruk (2013) and Pond Inlet (2014). Data shown are means \pm standard deviations.

\begin{tabular}{|c|c|c|c|}
\hline \multirow{2}{*}{ Location } & Sample Information & $\begin{array}{c}\text { Total Phosphorus } \\
(\mathbf{m g ~ P / L )}\end{array}$ & $\begin{array}{c}\text { Soluble Reactive } \\
\text { Phosphorus (mg P/L) }\end{array}$ \\
\hline \multirow{2}{*}{ Kugaaruk } & Start of the Treatment Season & $7.0 \pm 0.1$ & $5.6 \pm 0.1$ \\
\cline { 2 - 4 } & End of the Treatment Season & $9.8 \pm 0.1$ & $8.1 \pm 0.2$ \\
\hline \multirow{2}{*}{ Pond Inlet } & Start of the Treatment Season & $12.0 \pm 0.1$ & $10.0 \pm 0.2$ \\
\cline { 2 - 4 } & Middle of the Treatment Season & $12.2 \pm 0.1$ & $10.2 \pm 0.4$ \\
\cline { 2 - 4 } & End of the Treatment Season & $12.2 \pm 0.2$ & $9.7 \pm 0.2$ \\
\hline
\end{tabular}


Table 6: Phosphorus concentrations (expressed in $\mathrm{mg} \mathrm{P/g}$ dry sediment) for various fractions (as described in Lukkari et al. (2007)) from sediments collected from Kugaaruk (inlet, end of season, 2013, collected using custom buckets) and Pond Inlet (4 locations, middle and end of the treatment season, 2014, collected using acrylic bacon bomb sampler)

\begin{tabular}{|c|c|c|c|c|c|c|c|c|c|}
\hline \multirow{3}{*}{ Phosphorus Fraction } & \multirow{3}{*}{$\begin{array}{c}\text { Kugaaruk } \\
\text { Inlet }\end{array}$} & \multicolumn{8}{|c|}{ Pond Inlet } \\
\hline & & \multicolumn{2}{|c|}{$\begin{array}{l}\text { SW Corner } \\
\text { (Inlet) }\end{array}$} & \multicolumn{2}{|c|}{$\begin{array}{l}\text { NE Corner } \\
\text { (Outlet) }\end{array}$} & \multicolumn{2}{|c|}{ SE Corner } & \multicolumn{2}{|c|}{ Center } \\
\hline & & Middle & End & Middle & End & Middle & End & Middle & End \\
\hline $\begin{array}{l}\text { Pore water and loosely } \\
\text { bound }\end{array}$ & 0.30 & 0.24 & 0.17 & 0.16 & 0.05 & 0.10 & 0.19 & 0.33 & 0.36 \\
\hline $\begin{array}{l}\text { Redox sensitive Fe and } \\
\text { Mn oxide bound }\end{array}$ & 0.60 & 0.69 & 0.68 & 0.76 & 0.14 & 0.35 & 0.63 & 1.08 & 1.18 \\
\hline $\begin{array}{l}\text { Bound to } \mathrm{Al} \text { and non- } \\
\text { reducible Fe oxides }\end{array}$ & 0.50 & 1.10 & 2.14 & 2.44 & 0.30 & 0.70 & 2.16 & 1.83 & 3.25 \\
\hline Calcium bound & 0.05 & 0.13 & 0.40 & 0.02 & 0.09 & 0.01 & 0.14 & 0.16 & 0.28 \\
\hline Organic & 1.40 & 1.72 & 1.65 & 2.43 & 0.72 & 1.16 & 3.28 & 2.27 & 3.91 \\
\hline Total & 2.84 & 3.87 & 5.04 & 5.82 & 1.30 & 2.33 & 6.39 & 5.67 & 8.98 \\
\hline Mean $( \pm$ SD) & & \multicolumn{8}{|c|}{$\begin{array}{c}\text { Middle: } 4.42 \pm 1.65 \mathrm{mg} \text { P/g dry sediment } \\
\text { End: } 5.43 \pm 3.20 \mathrm{mg} \mathrm{P} / \mathrm{g} \text { dry sediment }\end{array}$} \\
\hline
\end{tabular}

